\title{
KARAKTERISTIK ORGANOLEPTIK DAN KANDUNGAN BETA-GLUKAN TEMPE KEDELAI DENGAN PENAMBAHAN SACCHAROMYCES CEREVISIAE
}

\author{
Characteristics of Sensory and Beta-Glucan Content of Soybean Tempe \\ With Addition of Saccharomyces cerevisiae
}

\author{
Samsul Rizal, Maria Erna Kustyawati \\ Jurusan Teknologi Hasil Pertanian - Fakultas Pertanian - Universitas Lampung \\ Jalan Sumantri Brojonegoro No. 1 Bandar Lampung \\ *Penulis Korespondensi: email: samsul.rizal@fp.unila.ac.id
}

Disubmit: 12 November 2018 Direvisi: 11 Juni 2019 Diterima: 19 Juni 2019

\begin{abstract}
ABSTRAK
Kapang, R. oligosporus merupakan mikroba utama yang berperan dalam fermentasi tempe. Penambahan khamir selama fermentasi tempe mempengaruhi kandungan aroma tempe dan diduga menghasilkan beta-glukan dalam tempe. Penelitian ini bertujuan untuk mengetahui pengaruh penambahan Saccharomyces cerevisiae terhadap sifat organoleptik dan kandungan betaglukan pada tempe. Perlakuan terdiri dari 2 faktor yaitu konsentrasi S. cerevisiae yang terdiri dari $1 \%$ dan $3 \%$, perlakuan kedua adalah cara pemasakan terdiri dari 2 taraf yaitu tempe digoreng dan dikukus. Sebagai kontrol dilakukan pengamatan terhadap tempe mentah. Pengujian organoleptik, sampel tempe diambil $15 \mathrm{~g}$ lalu dimasak sesuai perlakuan kemudian diamati secara organoleptik dengan uji skoring menggunakan 25 orang panelis. Data dianalisis dengan sidik ragam untuk mendapat penduga ragam galat dan uji signifikansi untuk mengetahui pengaruh antar perlakuan. Perbedaan antar perlakuan dianalisis menggunakan Duncan Multiple Range Test (DMRT) pada taraf 5\% untuk pengamatan terhadap sifat organoleptik tempe. Pengamatan sifat organoleptik dilakukan terhadap aroma langu, aroma khas tempe, rasa asam dan rasa pahit, dan penerimaan keseluruhan tempe. Hasil penelitian menunjukkan tempe yang dibuat dengan penambahan S. cerevisiae 1\% dan digoreng memiliki sifat organoleptik terbaik, yakni aroma khas tempe, bau langu lebih rendah, tidak berasa asam, dan tidak pahit. Meskipun berdasarkan skor penerimaan keseluruhan organoleptik, tempe yang diberi penambahan S. cerevisiae $1 \%$ dan digoreng lebih disukai panelis dibandingkan perlakuan lainnya, akan tetapi, penambahan S. cerevisiae 3\% menghasilkan tempe dengan kandungan beta-glukan lebih tinggi $(0,250 \%)$ dibanding penambahan S. cerevisiae $1 \%(0,181 \%)$.
\end{abstract}

Kata kunci : Beta-Glukan, Sifat Organoleptik, Saccharomyces cerevisia, Tempe Kedelai

\section{ABSTRACT}

Ryzopus oligosporus has been considered as the main microbe that plays a role in tempe fermentation. The addition of yeast in tempeh fermentation is known to affect the flavor of tempeh and produce beta-glucans in tempeh. This study aims to determine the effect of the addition of Saccharomyces cerevisiae in the tempe fermentation to the organoleptic properties and beta-glucan content in tempeh. The treatment consisting of 2 factors, namely the concentration of Saccharomyces cerevisiae consisted of $1 \%$ and $3 \%$, the second treatment was the method of cooking consisting of 2 levels, namely tempeh fried and steamed. As a control, observations were also made of raw tempeh. For organoleptic testing, tempe samples were taken 15 $g$ then cooked according to the treatment then observed organoleptically by scoring test using 25 panelists. Data were analyzed by analysis ov variance to obtain error estimators and significance tests to determine the effect between treatments. To find out the differences between treatments were analyzed using Duncan Multiple Range Test (DMRT) at the level of 5\% for observations of the organoleptic properties of tempeh. Observation of organoleptic properties was carried out on unpleasant aroma, typical aroma of tempeh, sour 
taste and bitter taste, and overall acceptance of tempeh. The results showed that the tempeh made with the addition of S. cerevisiae 1\% and fried had the best organoleptic properties. Although based on the overall organoleptic acceptance score, tempeh given $1 \%$ addition of S. cerevisiae and fried was preferred by panelists compared to other treatments, however, the addition of S. cerevisiae 3\% produced tempeh with higher beta-glucan content $(0,250 \%)$ than the addition of S. cerevisiae $1 \%(0,181 \%)$

Keywords : Beta Glucan, Characteristic of Sensory Soybean Tempe, Saccharomyces cerevisiae

\section{PENDAHULUAN}

Tempe merupakan makanan sumber protein yang sangat populer dengan kandungan gizi yang beranekaragam, seperti protein, lemak, karbohidrat, dan mineral. Tempe dibuat dengan cara memfermentasi kedelai dengan menginokulasikan jamur Rhizopus oligosporus. Proses fermentasi kacang kedelai menjadi tempe akan memperbaiki sifat fisik maupun komposisi kimia kedelai. Beberapa penelitian menunjukkan bahwa kandungan gizi tempe lebih mudah dicerna, diserap, dan dimanfaatkan oleh tubuh (Astuti, 2009; Kasmidjo, 1990; Roubos-van den Hil et al., 2010; Kadar et al., 2018). Hal ini dikarenakan kapang Rhizopus oligosporus yang tumbuh selama fermentasi kedelai mampu menghidrolisis senyawa-senyawa kompleks menjadi senyawa-senyawa sederhana yang mudah dicerna oleh manusia (Kasmidjo, 1990; Feng et al., 2007).

Selama ini, dalam proses fermentasi tempe, kapang adalah mikroba yang paling berperan dan disusul oleh bakteri. Proses fermentasi pada pembuatan tempe meliputi dua tahap, yaitu fermentasi oleh aktivitas bakteri yang berlangsung selama proses perendaman kedelai, dan fermentasi oleh kapang yang berlangsung setelah diinokulasi dengan kapang. Mulyowidarso et al. (1989) menyatakan bahwa bakteri merupakan mikroflora yang secara nyata selalu tumbuh selama fermentasi tempe dan mempunyai peran yang penting. Proses fermentasi dalam pembuatan tempe dapat mempertahankan sebagian besar zat-zat gizi yang terkandung dalam kedelai, meningkatkan daya cerna proteinnya, serta meningkatkan kadar beberapa macam vitamin B (Muchtadi dan Sugiyono, 2010).

Selain jamur dan bakteri yang sudah dipelajari keterlibatannya dalam fermentasi tempe, terdapat kemungkinan bahwa khamir (ragi) dapat tumbuh selama fermentasi tempe (Nout dan Kiers, 2005). Menurut Samson et al. (1987), beberapa jenis khamir telah dite- mukan terdapat dalam tempe yang dipasarkan dan selama perendaman kedelai untuk pembuatan tempe. Ditemukannya khamir dalam fermentasi tempe menunjukkan bahwa khamir mampu tumbuh dan berinteraksi dengan mikroflora lain yang terdapat dalam tempe dan kemungkinan khamir mempunyai peran dalam meningkatkan kualitas nutrisi dan flavor tempe (Kustyawati, 2009).

Salah satu jenis khamir yang ditemukan dalam fermentasi tempe adalah Saccharomyces cerevisiae. Oleh karena itu pada penelitian ini kultur Saccharomyces cerevisiae akan ditambahkan sebagai perlakuan dalam pembuatan tempe. Pemilihan Saccharomyces cerevisiae sebagai perlakuan penambahan inokulum dalam pembuatan tempe dengan pertimbangan karena khamir ini mampu memproduksi beta-glukan (Tonthowi et al., 2007) yang dikenal sebagai biological defense modifier (BDM). Beta-glukan, salah satu komponen dinding sel utama Saccharomyces cerevisiae, telah ditemukan dapat meningkatkan fungsi kekebalan tubuh. Sejumlah penelitian telah menunjukkan bahwa betaglukan memiliki aktivitas biologis sebagai immunomodulator dalam meningkatkan sistem kekebalan tubuh (Di Domenico et al., 2017), sebagai anti infeksi terhadap mikroorganisme yang meliputi bakteri, fungi, virus dan parasit (Hetland et al., 2013), sebagai antisitotoksik, anti-mutagenik, dan antitumorogenik (Widyastuti et al., 2011). Lee et al. (2001) juga menyatakan bahwa beta-glukan memiliki berbagai aktivitas biologis sebagai antitumor, antioksidan, antikolesterol, anti penuaan dini, dan peningkat sistem imun. Dengan demikian, penambahan khamir dalam fermentasi tempe, selain dapat meningkatkan kualitas nutrisi dan flavor tempe (Kustyawati et al., 2017) diharapkan juga mampu menghasilkan tempe yang mengandung beta-glukan, sehingga tempe yang dihasilkan memiliki keunggulan lebih disebabkan oleh kandungan beta-glukan tersebut. 
Penambahan Saccharomyces cerevisiae dalam pembuatan tempe dan cara pemasakan diharapkan mampu meningkatkan kualitas nutrisi dan karakterisitik sensori tempe. Penelitian ini bertujuan untuk mengetahui pengaruh penambahan Saccharomyces cerevisiae dan cara pemasakan terhadap sifat organoleptik (rasa dan aroma) dan kandungan beta-glukan tempe yang dihasilkan.

\section{METODE}

Bahan-bahan yang digunakan adalah kedelai, ragi tempe dengan merek dagang RAPRIMA, Media agar produksi Oxoid meliputi PDA, Malt Extract Agar (MEA), kultur Saccharomyces cerevisiae dalam bentuk ragi komersial (MerkFermipan), $\mathrm{NaOH} 2 \%$ dari Merck, Germany, $\mathrm{CH}_{3} \mathrm{COOH} 2 \mathrm{M}$, akuades, etanol, dan aluminium foil. Alat-alat yang digunakan antara lain autoklaf, spektrofotometer Sugar Free Contain (Merk Agilent Technologies, tipe Carry 100), inkubator dan alat-alat gelas untuk analisis mikrobiologi.

Penelitian ini dilakukan dengan metode Rancangan Acak Kelompok Lengkap (RAKL) yang terdiri dari dua perlakuan dan empat ulangan. Perlakuan pertama adalah penambahan Saccharomyces cerevisiae dengan dua taraf, yaitu 1\% dan 3\%. Perlakuan kedua adalah cara pemasakan tempe, yaitu tempe digoreng dan dikukus, serta tempe mentah sebagai kontrol. Data yang dihasilkan dianalisis dengan sidik ragam untuk mendapat penduga ragam galat dan uji signifikansi untuk mengetahui pengaruh antar perlakuan. Analisis lanjutan dilakukan dengan menggunakan Uji DMRT (Duncan's Multiple Range Test) pada taraf 5\% khusus untuk hasil pengamatan terhadap sifat organoleptik tempe.

\section{Pembuatan Tempe Kedelai}

Pembuatan tempe kedelai dengan penambahan Saccharomyces cerevisiae dilakukan berdasarkan penelitian Aptesia (2013). Tahapan yang dilakukan meliputi kedelai disortasi untuk dipilih biji kedelai yang baik dan padat, lalu dicuci menggunakan air yang mengalir sampai kotoran yang melekat terlepas dari biji kedelai. Selanjutnya kedelai direbus pada suhu $100{ }^{\circ} \mathrm{C}$ selama 30 menit dalam air yang mendidih sampai kulit ari mudah terkelupas. Biji kedelai direndam dalam air selama 24 jam. Kulit ari dikupas dari biji kedelai dan direbus lagi selama 30 menit, lalu ditiriskan dan didinginkan. Tahap peragian dilakukan dengan cara setiap 100 g kedelai ditambahkan ragi tempe sebanyak 0,2 g diaduk sampai rata dan ditambahkan Saccharomyces cerevisiae sesuai perlakuan (1 atau 3\%). Setelah tercampur rata, biji kedelai dimasukan dalam plastik pengemas yang telah dilubangi. Biji kedelai yang dimasukan tersebut masing-masing memiliki berat 20 g dalam setiap bungkusnya dan diberi label agar tidak tertukar. Biji kedelai tersebut diletakkan di atas tampah yang terbuat dari anyaman bambu. Setelah itu tampah diletakkan di atas rak yang terlindungi dari sinar/ cahaya, selanjutnya difermentasi pada suhu ruang yaitu sekitar $27-30{ }^{\circ} \mathrm{C}$ selama $36-48$ jam, kemudian setelah menjadi tempe dilakukan pengamatan meliputi uji organoleptik, penilaian $\mathrm{pH}$, dan analisis kandungan beta-glukan.

\section{Uji Organoleptik}

Penilaian sifat organoleptik dilakukan oleh 25 panelis yang berasal dari mahasiswa Jurusan Teknologi Hasil Pertanian Fakultas Pertanian Universitas Lampung dengan rentang usia 18-22 tahun yang sudah mendapatkan penjelasan (pelatihan) sebelum pengujian dilakukan. Penilaian sifat organoleptik dilakukan dengan mengikuti prosedur dari Nuraini dan Nawansih (2006). Penilaian organoleptik dilakukan terhadap rasa, aroma dan penerimaan keseluruhan tempe perlakuan dan dilakukan dengan uji skoring. Berdasarkan prosedur Nuraini dan Nawansih (2006), sebelum melakukan pengujian organoleptik, panelis melakukan Focus Group Discussing (FGD) untuk menentukan parameter rasa dan aroma yang akan digunakan dalam pengujian organoleptik. Pengujian sensori dengan teknik FGD melibatkan panelis dan moderator. Panelis melakukan pengujian bersama dalam satu ruangan dengan kondisi yang telah diatur agar bebas dari suara bising serta aroma-aroma yang dapat mengganggu penilaian panelis. Panelis dengan arahan moderator mendiskusikan dan menggali atribut sensori rasa dan aroma pada tempe. Sampel yang digunakan yaitu semua satuan percobaan yang terdiri dari kombinasi perlakuan konsentrasi Saccharomyces cerevisiae (konsentrasi Fermipan) $1 \%$ dan $3 \%$ dengan perlakuan pemasakan yaitu tempe mentah sebagai kontrol, tempe 
goreng, dan tempe kukus masing-masing sebanyak $15 \mathrm{~g}$. Setiap sampel diberi kode tiga angka acak. Panelis diminta untuk memberikan penilaian terhadap parameter organoleptik tempe yang terdiri dari aroma dan rasa dengan memberikan skor sesuai dengan kesan masing-masing. Skor penilaian aroma khas tempe terdiri dari 1 (sangat tidak khas tempe), 2 (tidak khas tempe), 3 (agak khas tempe), 4 (khas tempe), dan 5 (sangat khas tempe). Skor penilaian aroma langu pada tempe adalah 1 (sangat langu), 2 (langu), 3 (agak langu), 4 (tidak langu), dan 5 (sangat tidak langu). Skor penilaian aroma langu pada tempe Saccharomyces cerevisiae meliputi 1 (sangat asam), 2 (asam), 3 (agak asam), 4 (tidak asam), dan 5 (sangat tidak asam). Skor penilaian rasa pahit pada tempe meliputi 1 (sangat pahit), 2 (pahit), 3 (agak pahit), 4 (tidak pahit), dan 5 (sangat tidak pahit).

\section{Kandungan Beta-Glukan}

Penetapan kandungan beta-glukan pada tempe yang diberi penambahan Saccharomyces cerevisiae mengikuti metode yang digunakan oleh Kusmiati et al. (2007). Pengujian dilakukan dengan mengambil $1 \mathrm{~g}$ sampel tempe yang telah ditepungkan kemudian ditambahkan $\mathrm{NaOH}$ 0,7 N $30 \mathrm{ml}$. Selanjutnya, dihidrolisis selama 6 jam dengan suhu $75^{\circ} \mathrm{C}$. Selanjutnya didapat larutan keruh dan disentrifugasi dengan kecepatan $10000 \mathrm{rpm}$ pada suhu $25^{\circ} \mathrm{C}$ selama 30 menit. Selanjutnya, supernatan dibuang, dan didapat residu yang kemudian dicuci dengan $30 \mathrm{ml}$ larutan asam asetat $0,5 \mathrm{M}$ dan disentrifugasi kembali dengan kecepatan 10000 rpm pada suhu $25^{\circ} \mathrm{C}$ selama 30 menit kemudian supernatan dibuang. Pencucian dengan asam asetat tersebut dilakukan sebayak tiga kali.. Kemudian residu dicuci dengan $20 \mathrm{ml}$ akuades dan disentrifugasi dengan kecepatan 5000 rpm selama 10 menit. Pencucian dengan akuades dilakukan sebanyak dua kali.

Residu yang didapat ditambahkan dengan $20 \mathrm{ml}$ etanol lalu disentrifugasi dengan kecepatan $5000 \mathrm{rpm}$ selama 10 menit, sehingga menghasilkan beta-glukan (crud) basah. Biomassa tersebut dioven pada suhu $45^{\circ} \mathrm{C}$ selama 1 hari dan ditimbang sebagai berat beta-glukan (crud) kering/bobot betaglukan kasar. Residu kering tersebut ditambahkan $\mathrm{NaOH} 1 \mathrm{M} 4 \mathrm{ml}$ dan dibiarkan selama 1 jam. Larutan tersebut diencerkan dengan menggunakan akuades dan diaduk dengan shaker. Kemudian ditambahkan $\mathrm{Pb}$ Asetat $2 \mathrm{ml}$ dan didiamkan selama \pm 30 menit. Selanjutnya, larutan tersebut ditambahkan natrium oksalat $1 \mathrm{~g}$ sehingga didapat larutan yang jernih, kemudian larutan tersebut diambil $2 \mathrm{ml}$ dan ditambahkan fenol dan asam sulfat. kemudian diuji menggunakan spektrofoto-meter sugar free containt dengan panjang gelombang $490 \mathrm{~A}$.

\section{HASIL DAN PEMBAHASAN}

\section{Sifat Organoleptik}

Pengamatan organoleptik terhadap tempe yang diberi perlakuan penambahan Saccharomyces cerevisiae dan cara pemasakan yang berbeda terdiri dari parameter rasa dan aroma. Atribut sensori rasa dan aroma tempe selanjutnya ditentukan berdasarkan hasil Focus Group Discussion (FGD) dengan para panelisyang terdiri dari 25 orang mahasiswa yang sudah biasa menjadi panelis. Diskusi ini dilakukan untuk menentukan atribut sensori yang akan digunakan pada pengujian organoleptik. Metode FGD dilakukan setelah masing-masing panelis mencicipi satu per satu sampel tempe yang telah diberi perlakuan kemudian membahasnya dalam forum diskusi untuk menentukan atribut sensori dari rasa dan aroma.Adapun atribut sensori hasil FGD yang dipilih terdapat pada Tabel 1.

\section{Aroma Khas Tempe}

Hasil analisis sidik ragam menunjukkan bahwa konsentrasi Saccharomyces cerevisiae berpengaruh sangat nyata terhadap aroma khas tempe yang dihasilkan pada tempe. Hasil uji lanjut DMRT terhadap konsentrasi Saccharomyces cerevisiae menunjukkan perlakuan konsentrasi Saccharomyces cerevisiae $1 \%$ tidak berbeda nyata terhadap perlakuan Saccharomyces cerevisiae 3\%, meskipun perlakuan Saccharomyces cerevisiae 1\% memiliki skor yang lebih tinggi dibandingkan dengan perlakuan Saccharomyces cerevisiae 3\% dengan skor aroma masing-masing 3,870 dan 3,540 (Tabel 2). Dengan demikian, pengaruh konsentrasi Saccharomyces cerevisiae 1\% dan $3 \%$ tidak berbeda terhadap aroma khas tempe yang dihasilkan.

Hasil analisis sidik ragam menunjukkan bahwa jenis pemasakan sangat berpengaruh nyata terhadap aroma khas tempe 
Jurnal Teknologi Pertanian Vol. 20 No. 2 [Agustus 2019] 127-138

Karakteristik Organoleptik dan Kandungan Beta-Glukan Tempe Kedelai [Rizal dkk]

Tabel 1. Atribut sensori hasil focus group discussion (FGD)

\begin{tabular}{cc}
\hline Komponen Sensori & Atribut Sensori \\
\hline Aroma & Khas Tempe \\
Aroma & Langu \\
Rasa & Asam \\
Rasa & Pahit \\
\hline
\end{tabular}

Tabel 2. Hasil uji lanjut DMRT terhadap skor aroma khas tempe pada perlakuan konsentrasi

\begin{tabular}{cc}
\hline Perlakuan & Nilai Tengah \\
\hline Saccharomyces cerevisiae 1\% & $3.870^{\mathrm{a}}$ \\
Saccharomyces cerevisiae 3\% & $3.540^{\mathrm{a}}$ \\
\hline
\end{tabular}

Keterangan : Angka yang diikuti huruf yang sama menunjukkan tidak berbeda nyata pada taraf a $5 \%$ (berlaku pada kolom yang sama)

Tabel 3. Hasil uji lanjut DMRT aroma khas tempe terhadap faktor pemasakan tempe

\begin{tabular}{cc}
\hline Perlakuan & Nilai Tengah \\
\hline Tempe mentah (kontrol) & $3.770^{\mathrm{b}}$ \\
Tempe digoreng & $3.950^{\mathrm{a}}$ \\
Tempe dikukus & $3.395^{\mathrm{c}}$ \\
\hline
\end{tabular}

Keterangan : Angka yang diikuti huruf yang sama menunjukkan tidak berbeda nyata pada tarafa $5 \%$ (berlaku pada kolom yang sama)

Tabel 4. Hasil uji lanjut DMRT aroma langu terhadap faktor pemasakan tempe

\begin{tabular}{cc}
\hline Perlakuan & Nilai Tengah \\
\hline Tempe mentah (kontrol) & $3.170^{\mathrm{b}}$ \\
Tempe digoreng & $3.845^{\mathrm{a}}$ \\
Tempe dikukus & $3.140^{\mathrm{b}}$ \\
\hline
\end{tabular}

Keterangan : Angka yang diikuti huruf yang sama menunjukkan tidak berbeda nyata pada taraf a $5 \%$ (berlaku pada kolom yang sama)

Tabel 5. Hasil uji lanjut DMRT rasa asam terhadap faktor konsentrasi Saccharomyces cerevisiae

\begin{tabular}{cc}
\hline Perlakuan & Nilai Tengah \\
\hline Saccharomyces cerevisiae 1\% & $3.290^{\mathrm{a}}$ \\
Saccharomyces cerevisiae 3\% & $3.033^{\mathrm{b}}$ \\
\hline
\end{tabular}

Keterangan : Angka yang diikuti huruf yang sama menunjukkan tidak berbeda nyata pada taraf a $5 \%$ (berlaku pada kolom yang sama)

Tabel 6. Hasil uji lanjut DMRT rasa asam terhadap faktor pemasakan tempe

\begin{tabular}{cc}
\hline Perlakuan & Nilai Tengah \\
\hline Tempe mentah (kontrol) & $3.020^{\mathrm{b}}$ \\
Tempe digoreng & $3.535^{\mathrm{a}}$ \\
Tempe dikukus & $2.880^{\mathrm{c}}$ \\
\hline
\end{tabular}

Keterangan : Angka yang diikuti huruf yang sama menunjukkan tidak berbeda nyata pada taraf a $5 \%$ (berlaku pada kolom yang sama) 
Jurnal Teknologi Pertanian Vol. 20 No. 2 [Agustus 2019] 127-138

Karakteristik Organoleptik dan Kandungan Beta-Glukan Tempe Kedelai [Rizal dkk]

Tabel 7. Hasil uji lanjut DMRT terhadap skor rasa pahit pada perlakuan pemasakan tempe

\begin{tabular}{cc}
\hline Perlakuan & Nilai Tengah \\
\hline Tempe mentah (kontrol) & $3.355^{\mathrm{a}}$ \\
Tempe digoreng & $3.485^{\mathrm{a}}$ \\
Tempe dikukus & $3.015^{\mathrm{b}}$ \\
\hline
\end{tabular}

Keterangan: Angka yang diikuti huruf yangsama menunjukkan tidak berbeda nyata pada taraf a 5\% (berlaku pada kolom yang sama)

Tabel 8. Hasil uji lanjut DMRT penerimaan keseluruhan terhadap perlakuan konsentrasi Saccharomyces cerevisiae

\begin{tabular}{cc}
\hline Perlakuan & Nilai Tengah \\
\hline Saccharomyces cerevisiae 1\% & $3.210^{\mathrm{a}}$ \\
Saccharomyces cerevisiae 3\% & $3.010^{\mathrm{b}}$ \\
\hline
\end{tabular}

Keterangan: Angka yang diikuti huruf yang sama menunjukkan tidak berbeda nyata pada tarafa 5\% (berlaku pada kolom yang sama)

Tabel 9. Hasil uji lanjut DMRT terhadap skor penerimaan keseluruhan tempe pada perlakuan cara pemasakan tempe

\begin{tabular}{cc}
\hline Perlakuan & Nilai Tengah \\
\hline Tempe mentah (kontrol) & $3.070^{\mathrm{b}}$ \\
Tempe digoreng & $3.530^{\mathrm{a}}$ \\
Tempe dikukus & $2.730^{\mathrm{c}}$ \\
\hline
\end{tabular}

Keterangan: Angka yang diikuti huruf yang sama menunjukkan tidak berbeda nyata pada taraf a $5 \%$ (berlaku pada kolom yang sama)

Tabel 10. Rekapitulasi hasil pengujian organoleptik tempe yang diberi perlakuan Saccharomyces cerevisiae dan cara pemasakan berbeda

\begin{tabular}{cccccc}
\hline \multirow{2}{*}{ Perlakuan } & \multicolumn{5}{c}{ Parameter Organoleptik } \\
\cline { 2 - 6 } & $\begin{array}{c}\text { Aroma } \\
\text { langu }\end{array}$ & $\begin{array}{c}\text { Aroma khas } \\
\text { tempe }\end{array}$ & Rasa asam & $\begin{array}{c}\text { Rasa } \\
\text { pahit }\end{array}$ & $\begin{array}{c}\text { Penerimaan } \\
\text { keseluruhan }\end{array}$ \\
\hline $\begin{array}{c}\text { Tempe goreng + } \\
\text { S. cerevisiae 1\% }\end{array}$ & $3.970^{\mathrm{a}^{*}}$ & $4.160^{\mathrm{a}^{*}}$ & $3.710^{\mathrm{a}^{*}}$ & $3.520^{\mathrm{a}^{\mathrm{*}}}$ & $3.610^{\mathrm{a}^{*}}$ \\
$\begin{array}{c}\text { Tempe goreng + } \\
\text { S. cerevisiae 3\% }\end{array}$ & $3.720^{\mathrm{a}}$ & $3.74^{0} \mathrm{C}$ & $3.460^{\mathrm{b}}$ & $3.450^{\mathrm{a}}$ & $3.450^{\mathrm{b}}$ \\
$\begin{array}{c}\text { Tempe kukus + } \\
\text { S. cerevisiae 1\% }\end{array}$ & $3.120^{\mathrm{b}}$ & $3.500^{\mathrm{d}}$ & $3.070^{\mathrm{c}}$ & $3.140^{\mathrm{bc}}$ & $2.870^{\mathrm{d}}$ \\
$\begin{array}{c}\text { Tempe kukus + } \\
\text { S. cerevisiae 3\% }\end{array}$ & $3.160^{\mathrm{b}}$ & $3.290^{\mathrm{e}}$ & $2.690^{\mathrm{d}}$ & $2.890^{\mathrm{c}}$ & $2.590^{\mathrm{e}}$ \\
\hline
\end{tabular}

Keterangan:

1. Angka-angka yang diikuti huruf yang sama berarti tidak berbeda nyata pada uji Duncan taraf $5 \%$ dan uji Beda Nyata Terkecil (BNT) taraf 5\% (parameter kekerasan)

2. Tanda $(*)=$ perlakuan terbaik

3. Skor organoleptik yang semakin tinggi menunjukkan kriteria yang lebih baik

Tabel 11. Kandungan beta-glukan tempe dengan penambahan S. cerevisiae 1 dan $3 \%$ yang dimasak dengan cara digoreng

\begin{tabular}{cc}
\hline Sampel & Beta-glukan (\% w/w berat kering) \\
\hline Tempe (S. cerevisiae 1\% digoreng) & 0,181 \\
Tempe (S. cerevisiae 3\% digoreng) & 0,250 \\
\hline
\end{tabular}


yang dihasilkan. Hasil uji lanjut DMRT pada faktor pemasakan menunjukkan masingmasing perlakuan berbeda nyata terhadap perlakuan lainnya. Skor aroma khas tempe tertinggi terdapat pada tempe Saccharomyces cerevisiae yang dimasak dengan cara dikukus yaitu 3,950, Hasil uji lanjut DMRT skor aroma khas tempe terhadap faktor pemasakan disajikan pada Tabel 3.

Perubahan aroma tempe Saccharomyces cerevisiae ini disebabkan oleh pertumbuhan kapang dan khamir Saccharomyces cerevisiae selama proses fermentasi. Menurut Kustyawati (2009), pertumbuhan kapang dan Saccharomyces cerevisiae dapat mendorong pertumbuhan kapang dan mengubah kenampakan dan rasa tempe. Khamir akan berkontribusi pada interaksi antara mikroorganisme, perubahaan tekstur, dan biosintesa komponen flavor (Welthagen dan Vilijoen, 1999). Fermentasi kedelai dengan R.oligosporus dan S. boulardii, menghasilkan tempe dengan aroma harum manis yang menutupi aroma kedelai padau mumnya karena khamir mempunyai aktivitas proteolitik danlipolitik yang sangat tinggi sehingga mampu menghidrolisa protein maupun lemak menghasilkan asam amino, ester, asam lemak, etanol, acetaldehid, etil acetate, dan etil butirateyang merupakan komponen flavor dan aroma (Villijoen dan Greyling, 1995).

\section{Aroma Langu}

Hasil analisis sidik ragam menunjukkan cara pemasakan berpengaruh sangat nyata terhadap aroma langu pada tempe. Hasil uji lanjut DMRT pada perlakuan pemasakan terhadap skor aroma langu pada tempe menunjukkan bahwa tempe yang digoreng memiliki aroma yang berbeda nyata, yaitu lebih tinggi skornya dibandingkan dengan perlakuan lainnya (tempe mentah maupun tempe yang dikukus). Hasil uji lanjut dengan DMRT didapatkan bahwa tempe yang digoreng memiliki aroma yang tidak langu (Tabel 4). Tempe yang digoreng lebih tidak langu dibandingkan tempe mentah dan tempe yang dikukus.

Wihandini et al. (2012) menjelaskan bahwa bau langu terjadi karena aktivitas enzim lipoksigenase yang ada secara alami terdapat dalam kedelai. Enzim ini aktif saat biji kedelai pecah pada proses pengupasan kulit dan penggilingan karena kontak dengan udara (oksigen). Kandungan enzim lipoksigenase bervariasi antar varietas/galur kede- lai sehingga intensitas langu masing-masing varietas kedelai juga bervariasi. Hilangnya aroma langu ini disebabkan pengaruh pemanasan selama penggorengan tempe yang menyebabkan terjadinya inaktivasi enzim lipoksigenase.

Aroma tempe yang dihasilkan pada fermentasi tempe terbentuk karena adanya aktivitas enzim dari kapang yang digunakan. Enzim ini akan memecah protein dan lemak kedelai membentuk aroma yang khas. Komponen aroma yang dihasilkan memiliki ukuran dan berat molekul yang lebih kecil dari bahan awalnya sehingga komponen lebih mudah menguap (volatil) dan tercium sebagai bau tempe. Aroma yang muncul tergantung pada jenis komponen yang dihasilkan selama proses fermentasi (Wihandini et al., 2012).

\section{Rasa Asam}

Semakin tinggi nilai skor rasa asam maka semakin tidak asam rasa tempe yang dihasilkan. Analisis ragam terhadap data skor rasa asam tempe menunjukkan bahwa konsentrasi Saccharomyces cerevisiae dan jenis pemasakan sangat berpengaruh terhadap rasa asam tempe Saccharomyces cerevisiae yang dihasilkan. Hasil uji lanjut DMRT pada faktor konsentrasi Saccharomyces cerevisiaemenunjukkan bahwa perlakuan konsentrasi Saccharomyces cerevisiae 1\% dan 3\% saling berbeda nyata terhadap rasa asam tempe Saccharomyces cerevisiae. Skor rasa asam tertinggi terdapat pada tempe yang diberi penambahan Saccharomyces cerevisiae $1 \%$ yaitu 3,290 (agak asam), sedangkan perlakuan konsentrasi Saccharomyces cerevisiae $3 \%$ menghasilkan tempe dengan skor rasa asam 3,033 (agak asam). Hasil uji lanjut skor rasa asam pada tempe yang diberi perlakuan konsentrasi Saccharomyces cerevisiae disajikan pada Tabel 5 .

Pada faktor pemasakan, hasil uji lanjut DMRT menunjukkan bahwa semua perlakuan, baik kontrol (tempe mentah), pemasakan dengan penggorengan, maupun pemasakan dengan cara pengukusan berbeda nyata antara perlakuan satu dengan perakuan lainnya terhadap rasa asam tempe yang dihasilkan. Skor rasa asam tertinggi terdapat pada tempe Saccharomyces cerevisiae yang dimasak dengan cara digoreng yaitu 3,535 (cenderung tidak asam). Perlakuan kontrol (tempe mentah) memiliki skor rasa asam 3,020 (agak asam), sedangkan perlakuan P3 
(pengukusan) menghasilkan tempe dengan skor rasa asam 2,880 (cenderung agak asam). Hasil uji lanjut rasa asam pada faktor pemasakan disajikan pada Tabel 6.

Rasa asam pada tempe Saccharomyces cerevisiae timbul karena pengaruh fermentasi yang melibatkan Saccharomyces cerevisiae. Hal ini sesuai dengan penelitian Muin et al. (2015) yang menyatakan bahwa dalam fermentasi pembuatan bioetanol $\mathrm{pH}$ lingkungan cenderung asam karena dalam pembentukan etanol, juga terjadi pembentukan asam asetat sebagai produk sampingnya. Hasil ini juga sesuai dengan penelitian Rakhmadani (2013) yang menyatakan bahwa akibat penggunaan etanol sebagai sumber energi bagi Saccharomyces cerevisiae saat proses fermentasi berlangsung, maka terjadi peningkatan pembentukan asam asetat sehingga $\mathrm{pH}$ lingkungan menjadi asam.

\section{Rasa Pahit}

Semakin tinggi skor penilaian rasa tempe berarti semakin tidak pahit. Hasil analisis sidik ragam menunjukkan bahwa rasa pahit tempe dipengaruhi secara nyata oleh perlakuan cara pemasakan. Hasil uji lanjut DMRT terhadap hasil penilaian rasa pahit tempe yang mengandung Saccharomyces cerevisiae pada perlakuan pemasakan menunjukkan bahwa pemasakan dengan cara pengukusan berbeda nyata terhadap perlakuan cara pemasakan lainnya dengan skor 3,015 (agak pahit). Skor rasa pahit tertinggi diperoleh pada tempe yang dimasak dengan cara digoreng, yaitu skor 3,485 (mendekati tidak pahit). Hasil uji lanjut terhadap skor rasa pahit tempepada perlakuan pemasakan disajikan pada Tabel 7.

Fermentasi kedelai dengan $R$. oligosporus dan $S$. boulardii menghasilkan tempe dengan aroma harum-manis yang menutupi aroma langu kedelai pada umumnya karena yeast mempunyai aktivitas proteolitik dan lipolitik yang sangat tinggi (Kustyawati, 2009). Aktivitas protiolitik dan lipolitik mikroba mampu menghidrolisa protein maupun lemak menghasilkan asam amino, ester, asam lemak, etanol, asetaldehid, ethil asetat dan etil butirat yang merupakan komponen flavor dan aroma (Villijoen dan Greyling, 1995).

\section{Penerimaan Keseluruhan}

Penerimaan keseluruhan merupakan parameter pengamatan organoleptik yang mencakup parameter aroma langu, aroma khas tempe, rasa asam, dan rasa pahit pada tempe yang diberi perlakuan penambahan Saccharomyces cerevisiae dengan cara pemasakan yang berbeda. Berdasarkan hasil pengujian organoleptik, skor penerimaan keseluruhan tertinggi pada perlakuan konsentrasi Saccharomyces cerevisiae dimiliki oleh tempe dengan penambahan Saccharomyces cerevisiae $1 \%$, sedangkan pada perlakuan pemasakan skor tertinggi dimiliki oleh tempe yang dimasak dengan cara digoreng. Hasil analisis sidik ragam menunjukkan bahwa konsentrasi Saccharomyces cerevisiae dan perlakuan cara pemasakan berpengaruh sangat nyata terhadap penerimaan keseluruhan tempe Saccharomyces cerevisiae, sedangkan interaksi antara konsentrasi Saccharomyces cerevisiae dan cara pemasakan tidak berpengaruh nyata terhadap penerimaan keseluruhan tempe yang dihasilkan. Hasil uji lanjut DMRT pada perlakuan konsentrasi Saccharomyces cerevisiae menunjukkan bahwa perlakuan konsentrasi Saccharomyces cerevisiae 1\% berbeda nyata dengan perlakuan konsentrasi 3\%. Hasil uji lanjut penerimaan keseluruhan terhadap tempeyang diberi Saccharomyces cerevisiaepada perlakuan konsentrasi Saccharomyces cerevisiae disajikan pada Tabel 8 .

Hasil uji lanjut DMRT terhadap penerimaan keseluruhan tempe Saccharomyces cerevisiae pada perlakuan cara pemasakan menunjukkan bahwa perlakuan kontrol (tempe mentah) berbeda nyata dengan perlakuan penggorengan dan pengukusan. Skor penerimaan keseluruhan tertinggi diperoleh pada tempe Saccharomyces cerevisiae yang dimasak dengan cara digoreng yaitu 3,53 (disukai). Sementara itu, skor penerimaan keseluruhan untuk tempe mentah (tanpa pemasakan) dan tempe yang dikuus adalah 3,070 (agak disukai) dan 2,730 (cenderung agak disukai). Hasil uji lanjut penerimaan keseluruhan terhadap faktor pemasakan disajikan pada Tabel 9 .

Hasil penelitian Gultom (2009) menunjukkan bahwa pada pengujian organoleptik tempe, penambahan fermipan 1\% menghasilkan tempe yang lebih disukai panelis dibandingkan dengan tempe dengan penambahan ragi tempe biasa dan tempe dengan penambahan biakan murni Saccharomyces cerevisiae. Kesukaan panelis ini dikarenakan aromanya yang khas tempe dan sedikit lebih harum, rasanya yang disukai, tekstur yang kompak dan juga miselium yang banyak. 


\section{Perlakuan Terbaik}

Pemilihan perlakuan terbaik dilakukan berdasarkan pada parameter organoleptik yang meliputi aroma langu, aroma khas tempe, rasa asam, rasa pahit, dan penerimaan keseluruhan pada tempe yang digoreng dan dikukus dengan skor tertinggi. Rekapitulasi hasil analisis organoleptik terhadap tempe dengan perlakuan konsentrasi Saccharomyces cerevisiae dan cara pemasakan berbeda disajikan pada Tabel 10. Pemilihan perlakuan terbaik dengan cara membandingkan sifat organoleptik tempe antar perlakuan penambahan Saccharomyces cerevisiae 1\% dengan 3\% dan perlakuan cara pemasakan dengan digoreng dan dikukus.

Pada Tabel 10 dapat dilihat bahwa berdasarkan penilaian organoleptik maka perlakuan penambahan Saccharomyces cerevisiae $1 \%$ dan cara pemasakannya dengan digoreng merupakan perlakuan terbaik. Tempe pada perlakuan tersebut memiliki skor penilaian parameter organoleptik tertinggi pada semua parameter organoleptik dibandingkan dengan perlakuan lainnya. Tempe yang diperoleh dengan penambahan Saccharomyces cerevisiae $1 \%$ dan dimasak dengan cara digoreng memiliki aroma tidak langu; aroma khas tempe; rasa agak asam; rasa agak pahit.

\section{Kandungan Beta Glukan}

Analisis kandungan beta-glukan dilakukan pada tempe yang telah digoreng baik dengan penambahan Saccharomyces cerevisiae $1 \%$ maupun $3 \%$. Hal ini dikarenakan tempe yang dimasak dengan cara digoreng merupakan tempe terbaik berdasarkan penilaian organoleptik. Hasil pengujian beta-glukan menunjukkan bahwa tempe yang dibuat dengan penambahan Saccharomyces cerevisiae 3\% memiliki kandungan beta-glukan lebih tinggi dibandingkan dengan tempe yang dibuat dengan penambahan Saccharomyces cerevisiae $1 \%$, meskipun dari segi organoleptik tempe dengan Saccharomyces cerevisiae 1\% lebih disukai (Tabel 11). Kandungan beta-glukan dalam tempe disebabkan adanya penambahan Saccharomyces cerevisiae pada proses fermentasi tempe. Hal ini dibuktikan dengan meningkatnya jumlah beta-glukan tempe seiring dengan meningkatnya jumlah Saccharomyces cerevisiae yang ditambahkan.

Tabel 11 menunjukkan bahwa tempe dengan perlakuan terbaik berdasarkan parameter organoleptik, yaitu tempe yang di goreng dengan penambahan Saccharomyces cerevisiae $1 \%$ memiliki kandungan beta-glukan $0,181 \%$, sedangkan dengan penambahan Saccharomyces cerevisiae 3\% memiliki kandungan beta gluka lebih tinggi yaitu $0,25 \%$. Meskipun secara organoleptik perlakuan yang terbaik adalah tempe yang diberi perlakuan penambahan Saccharomyces cerevisiae $1 \%$ dan dimasak dengan cara digoreng (Tabel 10), akan tetapi penambahan Saccharomyces cerevisiae yang direkomendasikan untuk digunakan adalah Saccharomyces cerevisiae 3\% karena kandungan beta-glukan tempe yang dihasilkan lebih tinggi yaitu $0,250 \%$. Hal ini karena target dari penambahan Saccharomyces cerevisiae pada pembuatan tempe ini adalah adanya kandungan beta-glukan pada tempe yang dihasilkan. Meskipun tempe dengan penambahan Saccharomyces cerevisiae $3 \%$ bukan merupakan yang terbaik secara organoleptik, akan tetapi skor penilaian penerimaan keseluruhan kedua perlakuan penambahan Saccharomyces cerevisiae 1\% dan 3\% masih dalam kisaran yang sama yaitu 3,610 dan 3,450 (cenderung disukai).

Beta-glukan merupakan homopolimer glukosa yang diikat melalui ikatan $B-(1,3)$ dan 8 -(1,6)-glukosida (Figueroa dan Stafollo, 2019) dan banyak ditemukan pada dinding sel beberapa bakteri, tumbuhan, dan khamir (Hunter et al., 2002). Salah satu khamir uniseluler yang tersebar luas di alam dan merupakan galur potensial penghasil beta-glukan adalah Saccharomyces cerevisiae, karena sebagian besar dinding selnya tersusun atas betaglukan (Lee et al., 2001; Dietrich-Muszalska et al., 2011; Li et al., 2018; Hong et al., 2019). Mikrobia ini bersifat nonpatogenik dan nontoksik, sehingga sejak dahulu banyak digunakan dalam berbagai proses fermentasi seperti pada pembuatan roti, asam laktat, dan alkohol (Lee, 1992). Beta-glukan dapat digunakan sebagai zat aditif pada makanan (Cheeseman dan Brown, 2019; Yuan et al., 2019). Zat-zat yang terkandung dalam betaglukan dapat merangsang sistem kekebalan tubuh, modulasi imunitas humoral dan selular, dengan demikian memiliki efek menguntungkan dalam memerangi infeksi bakteri, virus, jamur dan parasit (Widyastuti et al., 2011). Dengan demikian, kandungan betaglukan dalam tempe diharapkan akan meningkatkan nilai lebih tempe selain keunggulan tempe yang sudah dikenal selama ini. Tempe Saccharomyces cerevisiae yang mengandung beta-glukan diharapkan memiliki peran positif bagi kesehatan sebagaimana 
fungsi beta-glukan itu sendiri, meskipun hal ini perlu pembuktian melalui penelitian lebih lanjut.

\section{SIMPULAN}

Berdasarkan penelitian yang telah dilakukan dapat disimpulkan bahwa penambahan Saccharomyces cerevisiae dan cara pemasakan berpengaruh sangat nyata terhadap rasa asam, aroma khas tempe dan penerimaan keseluruhan pada tempe. Berdasarkan parameter organoleptik, tempe yang diberi perlakuan Saccharomyces cerevisiae 1\% dan dimasak dengan cara digoreng lebih disukai oleh panelis dibandingkan perlakuan lainnya. Penambahan Saccharomyces cerevisiae berpengaruh terhadap kandungan beta-glukan tempe dan kandungan beta-glukan tertinggi terdapat pada tempe dengan penambahan Saccharomyces cerevisiae 3\% dengan perlakuan pemasakan digoreng, yaitu sebesar $0,25 \%$.

\section{UCAPAN TERIMA KASIH}

Ucapan terima kasih ditujukan kepada Kementerian RistekDikti yang telah membantu pendanaan penelitian melalui skim Penelitian Fundamental atau Penelitian Dasar Unggulan Perguruan Tinggi tahun 2017.

\section{DAFTAR PUSTAKA}

Aptesia, L, -T., 2013. Pemanfaatan Lacto-bacillus Casei dan Tapioka dalam Upaya Menghambat Kerusakan Tempe Kedelai. Skripsi. Universitas Lampung. Bandar Lampung.

Astuti, -S., 2009. Profil antioksidan copper, zinc-superoxide dismutase $(\mathrm{Cu}, \mathrm{Zn}$ SOD) pada tubuli seminiferi testistikus yang diberi tepung kedelai kaya isoflavon, Seng $(\mathrm{Zn})$ dan vitamin E. Prosiding Seminar Hasil-hasil Penelitian Unila-Dies ke 44. Bandar Lampung.

Cheeseman, I, M, Brown, jr, R, M, 2000. Microscopy of curdlan structure. Dilihat 20 Januari 2019. <http:/ / www.botany. utexas.edu/lab/ongres/icheese.htm>

Di Domenico, -J., Canova, -R., Soveral, L, -F.,
Nied, C, -O., Costa, M, -M., Frandoloso, -R., Kreutz, L, -C., 2017. Immunomodulatory effects of dietary $\beta$-glucan in silver catfish (Rhamdia quelen). Pesquisa Veterinária Brasileira. 37(1), 73-78. http://dx.doi. org/10.1590/s0100-736x2017000100012

Dietrich-Muszalska, -A., Olas, -B., Kontek, -B., Rabe-Jablonska, -J., 2011. Beta-glucan from Saccharomyces cerevisiae reduces plasma lipid peroxidation induced by haloperidol. International Journal of Biological Macromolecules. 49, 113-116. https:/ / doi.org/10.1016/j.ijbiomac.2011.03.007

Feng, X, -M., Larsen, T, -O., Schnurer, -J., 2007. Production of volatile compounds by Rhizopus oligosporus during soybean and barley tempeh fermentation. International Journal of Food Microbiology. 113(2), 133-141. https://doi. org/10.1016/j.ijfoodmicro.2006.06.025

Figueroa, L, -E., Stafollo, M, -D., 2019. Dietary Fiber (Psyllium, $\beta$-Glucan). Encyclopedia of Food Chemistry. 2019, 61-69. https://doi.org/10.1016/ B978-0-08100596-5.22342-1

Gultom, U, -Y., 2009. Kajian Penambahan Yeast (Saccharomyces cereviciae) Terhadap Kandungan Nutrisi dan Sifat Organoleptik Tempe. Skripsi. Universitas Lampung. Bandar Lampung

Hetland, -G., Johnson, -E., Eide, D, -M., Grinde, -B., Samuelsen, A, B, -C., Wiker, H, -G., 2013. Antimicrobial effects of $\beta$-glucans and pectin and of the $A g$ ricus blazei based mushroom extract, andoSan TM. Examples of mouse models for pneumococcal, fecal bacterial, and mycobacterial infections. Microbial pathogens and strategies for combating them: science, technology and education (A. Méndez-Vilas, Ed.). https://www.researchgate.net/ publication/304620924_Antimicrobial_effects_of_b-glucans_and_pectin_ and_of_the_agaricus_Blazei-based_ mushroom_extract_andosan_examples_of_mouse_models_for_pneumococcal-_fecal_bacterial-_and_mycobacterial_infections

Hong, J, -Y., Son, S, -H., Hong, S, -P., Yi, S, -H., Kang, S, -H., Lee, N, -K., Paik, H, -D., 2019. Production of $\beta$-glucan, glutathione, and glutathione derivatives by probiotic Saccharomyces cerevisiae isolated from cucumber jangajji. LWT. 100, 114-118. https://doi. 
org/10.1016/j.lwt.2018.10.048

Hunter, K, -W., Gault, R, -A., Berner, M, -D., 2002. Preparation of microparticulate beta-glucan from Saccharomyces cerevisiae for use in immune potentiation. Letters in Aplied Microbiology. 35(4), 267-271. https://onlinelibrary.wiley. com/doi/full/10.1046/j.1472-765X.20 02.01201.x?sid=nlm\%3Apubmed

Kadar, A, -D., Aditiawati, -P., Astawan, -M., Putri, S, -P., Fukusaki, -E., 2018. Gas chromatography coupled with mass spectrometry-based metabolomics for the classification of tempe from different regions and production processes in Indonesia. Journal of Bioscience and Bioengineering. 126(3), 411-416. https:/ / doi.org/10.1016/j.jbiosc.2018.03.020

Kasmidjo, R, -B., 1990. Tempe: Mikrobiologi dan Kimia Pengolahan serta Pemanfaatannya. PAU Pangan dan Gizi UGM, Yogyakata

Kusmiati., Swasono , Tamat, S, -R., Nuswantara, -S., Isnaini, -N., 2007. Produksi dan penetapan kadar $\beta$-glukan dari tiga galur Saccharomyces cerevisiae dalam media mengandung molase. Jurnal Ilmu Kefarmasian Indonesia. 5(1), 7-16. http://jifi.farmasi.univpancasila.ac.id/index.php/jifi/article/ view/582

Kustyawati, M, -E., 2009. Kajian peran yeast dalam pembuatan tempe. Agritech. 29, 64-70. https://doi.org/10.22146/ agritech. 9765

Kustyawati, M, -E., Nawansih, -O., Nurdjanah, -S., 2017. Profile of aroma compounds and acceptability of modified tempeh. International Food Research Journal. 24(2), 734-740. http://www. ifrj.upm.edu.my / $24 \% 20(02) \% 202017$ / (38).pdf

Lee, J, -N., Lee, D, -Y., Ji, I, -H.,Kim, G, -E., Kim, H, -N., Sohn, -J., Kim, -S., Kim, C, $-W ., 2001$. Purification of soluble beta-glucan with immune-enhancing activity from the cell wall of yeast. Bioscience, Biotechnology, and Biochemistry. 65, 837. https://doi.org/10.1271/ bbb.65.837

Lee, J, -M., 1992. Biochemical Engineering. Prentice Hall, New Jersey

Li, -F., Wang, -Z., Liu, -J., Li, -W., 2018. Radioprotective effect of orally administered beta-d-glucan derived from Saccharomyces cerevisiae. International Journal of Biological Macromolecules. 115, 572-
579. https://doi.org/10.1016/j.ijbiomac.2018.04.098

Muchtadi, T, -R., Sugiyono. 2010, Ilmu Pengetahuan Bahan Pangan. Alfabeta, Bandung.

Muin, -S., Hakim, -I., Febriansyah, -A., 2015. Pengaruh waktu fermentasi dan konsentrasi enzim terhadap kadar bioetanol dalam proses fermentasi nasi aking sebagai substrat organik. Jurnal Teknik Kimia. 21, 59-69. http:/ / jtk.unsri.ac.id/index.php/jtk/article/ view/218

Mulyowidarso, R, -K., Fleet, G, -H., Buckle, K, -A., 1989. The microbial ecology of soybean soaking for tempe production. International Journal of Food Microbiology. 8(1), 35-46. https://doi. org/10.1016/0168-1605(89)90078-0

Nout, M, J, -R., Kiers, J, -L., 2005. A review: tempe fermentation, innovation and functionality: update into he third millennium. Journal of Applied Microbiology. 98(4), 789-805. https://doi. org/10.1111/j.1365-2672.2004.02471.x

Nuraini, -F., Nawansih, -O., 2006. Uji Sensori. Universitas Lampung

Rakhmadani, A, -H., 2013. Studi Pemanfaatan Limbah Makanan Sebagai Bahan Penghasil Etanol untuk Biofuel Melalui Proses Hidrolisis pada Kecepatan Pengadukan dan Waktu Fermentasi yang Berbeda. Tesis. Universitas Diponegoro. Semarang

Roubos-van den Hil, P, -J., Rob Nout, M, -J., Van der Muelen, -J., Gruppen, -H., 2010. Bioactivity of tempe by inhibiting adhesion of ETEC to intestinal cells, as influenced by fermentation substrates and starter pure cultures. Food Microbiology. 27(5), 638-644. https://doi. org/10.1016/j.fm.2010.02.008

Samson, R, -A., Kooij, -V., de Boer, -E., 1987. Microbiological quality of commercial tempeh in the Netherlands. Journal of Food Protection. 50, 9294. https://doi. org/10.4315/0362-028X-50.2.92

Tonthowi, -A., Kusmiati, Nuswantara, -S., 2007. Produksi $\beta$-Glukan Saccharomyces cerevisiae dalam media dengan sumber nitrogen berbeda pada air-lift Fermentor. Biodiversitas. 8(4), 253-256. https:// doi.org/10.13057/biodiv/d080401

Villijoen, B, -C., Greyling, -T., 1995. Yeast associated with cheddar and gouda making. International Journal of Food 
Jurnal Teknologi Pertanian Vol. 20 No. 2 [Agustus 2019] 127-138

Karakteristik Organoleptik dan Kandungan Beta-Glukan Tempe Kedelai [Rizal dkk]

Microbiology. 28, 79-88. https://doi. org/10.1016/0168-1605(94)00114-L

Welthagen, J, -J., Vilijoen, B, -C., 1999. The isolation and identification of yeasts obtained during the manufacture and ripening of cheddar cheese. Food Microbiology. 16(1), 63-73. https://doi. org/10.1006/fmic.1998.0219

Widyastuti, N., Baruji, -T., Giarni, -R., Isnawan, -H., Wahyudi, -P., Donawati., 2011. Analisa kandungan beta-glukan larut air dan larut alkali dari tubuh buah jamur tiram (Pleurotus ostreatus) dan shitake (Lentimus edodes). Jurnal Sains dan Teknologi Indonesia. 13(3), 182191. http://dx.doi.org/10.29122/jsti. v13i3.894

Wihandini, D, -B., Arsanti, -L., Wijarnaka, -A., 2012. Sifat fisik, kadar protein, dan uji organoleptik tempe kedelai hitam dan tempe kedelai kuning dengan berbagai metode pemasakan. Nutrisia. 14(1), 1-61

Yuan, -B., Ritzoulis, -C., Chen, -J., 2019. Rheological investigations of beta glucan functionality: Interactions with mucin. Food Hydrocolloids. 87, 180-186. https:/ / doi.org/10.1016/j.foodhyd.2018.07.049 